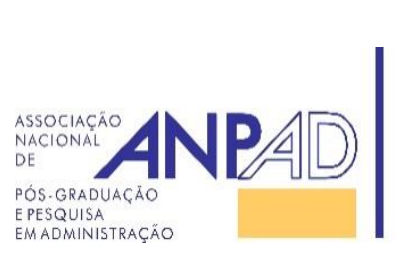

Available online at http://www.anpad.org.br/bar

BAR, Rio de Janeiro, v. 14, n. 3 , art. 4, e170005, 2017

\title{
The Influence of Organizational Reconciliation Policies and Culture on Workers Stress Perceptions
}

\author{
Rosa Monteiro ${ }^{1,2}$ \\ Marta Pereira ${ }^{1}$ \\ Fernanda Daniel ${ }^{1,4}$ \\ Alexandre Gomes da Silva ${ }^{3,4}$ \\ Fátima Regina Ney Matos ${ }^{1}$ \\ Instituto Superior Miguel Torga ${ }^{1}$
}

Centro de Estudos Sociais da Universidade de Coimbra ${ }^{2}$ Instituto Superior de Contabilidade e Administração de Coimbra ${ }^{3}$ Centro de Estudos e Investigação em Saúde da Universidade de Coimbra ${ }^{4}$

Received 20 January 2017; received in revised form 26 June 2017; accepted 18 August 2017; 


\begin{abstract}
Work-family reconciliation plays a crucial role in the well-being of employees, having impacts at the individual, social and organizational level. Studies concluded that poor work-life balance as one of the ten predictors of psychosocial risks at work. A family-friendly culture relates to how an organization values and allows the articulation of the various spheres of its workers' life. We intended to determine the effect of different variables like the existence of services, the organizational culture and the managers and colleagues support, on the stress experienced. A sample of 156 employees, from five organizations in the same region of Portugal, responded to a survey contributing to the empirical results of the study. We have conducted a structural equation model to test whether the factor solution of the perception of the reconciliation capability - STRESS model demonstrated a goodness of fit to the population studied. We've concluded that more important than the existence of reconciliation services, the perception of a supportive organizational culture, namely by colleagues and supervisors has great influence in reconciliation capability and by that way on work stress feelings. This might explain why workers do not use all the spectrum of resources provided by organizations and states to work-life reconciliation.
\end{abstract}

Key words: work-life reconciliation; organizational support; diversity and gender issues; reconciliation capability; work stress. 


\section{Introduction}

Understand how individuals react and deal with the tension between work and family has impacts for themselves and for the organizations where they work (Carlson \& Kacmar, 2000; Esson, 2004; Friedman \& Greenhaus, 2000; Karkoulian, Srour, \& Sinan, 2016; Nohe, Meier, Sonntag, \& Michel, 2015; Xie, Shi, \& Ma, 2017). At the individual level, the reconciliation difficulties are identified as a source of mental and physical stress, with negative consequences on health, disruptions in the performance of parental roles, anxiety, depression and dissatisfaction. In relational terms it can lead to increased interpersonal conflicts, for example (Xie et al., 2017). At the organizational level, they are associated with decreased productivity, absenteeism, higher turnover, low morale, reduced job satisfaction, stress and burnout and therefore, loss of talents. Promoting conditions of reconciliation and reducing tensions between the different spheres of life, thus becomes not only a way to promote equal opportunities and results for men and women, but also to promote organizational efficiency, estimating its impact in terms of reduced stress and improving levels of satisfaction, motivation and productivity (Esson, 2004; Friedman \& Greenhaus, 2000; Karkoulian et al., 2016).

The European Survey Quality of Life in a Changing Europe (Byrne \& Pachana, 2011; Lippe, Dulk, Doorne-Huiskes, Lane, \& Bäck-Wiklund, 2009) concluded that Portugal is the European country with lower levels of satisfaction with work-family reconciliation, alongside the UK, Hungary, Bulgaria and Finland, and contrasting with Sweden, the Netherlands and Germany (Rodrigues, Barroso, \& Caetano, 2010). The Second European Quality of Life Survey (European Foundation for the Improvement of Living and Working Conditions [Eurofound], 2009) states that people in Portugal, as in Greece and Italy, have a relatively low level of life satisfaction and happiness and a lower sense of life fulfilment; indeed, with regard to the level and patterns of subjective well-being. Also a recent study of the Portuguese Association of Occupational Health Psychology (Cunha, Pereira, \& Cunha, 2014) gives an account of a severe decrease in the levels of engagement and perception of work-family interface in 2008-2013, with a consequent increase of stress and burnout. It also identifies the increased perception of overload and fatigue, with $78 \%$ of the individuals of the sample that revealed an intention to leave the job (turnover).

The European Foundation for the Improvement of Living and Working (Eurofound, 2007, p. 5) pointed out the "balance between professional and personal life" as one of the four dimensions analyzed in the study of quality of life at work (being the others, the possibility of skills development, contractual and employment security, health and wellness in the workplace). Similarly, the European Agency for Safety and Health at Work identifies the "poor work-life balance" (Brun \& Milczarek, 2007, p. 9) as one of the ten predictors of psychosocial risks at work. This along with other emerging risks related to the reconciliation such as the new contractual forms and job insecurity, the aging of the working population, the intensification of work, and forms of offensive behaviour, in the context of crisis and austerity experienced recently in Europe (Lewis, Anderson, Lyonette, Payne, \& Wood, 2016). There is, therefore, a growing recognition of the weight of non-material factors in the satisfaction and well-being expressed by individuals in professional life, with emphasis on work-family reconciliation issues (Rodrigues et al., 2010).

The combination of an extremely demanding job market, with the lack of support and flexibility in the workplace, based on a logic of presenteeism and intensity (Mimoso, 2013; Yaphe, 2015) unpredictability and atypical hourly schemes, joined with declining support of the extended family results in long working hours and lack of time for the family, experienced by many working women and men.

The growing recognition of the relationship between work and family has legitimate research on the subject, as well as the development of public policies and organizational practices to promote reconciliation between work, family and personal realms. This is based on the assumption that workers have other existential spheres and responsibilities that should be harmonized (Monteiro \& Ferreira, 2013). Scientific approaches arise from a variety of analytical sources. They connect the issue of 
reconciliation with the studies of gender and equality, with the management of diversity, with the practices of corporate social responsibility, with public policies to support families and state Welfare provisions, and finally with concerns about the psychosocial conditions at work, risk, stress, burnout and their individual, social and organizational/economic consequences (Monteiro, 2014).

In this work, we have conducted a structural equation model to test whether the factor solution of the perception of the reconciliation capability - STRESS model demonstrated a goodness of fit to the population studied. We intended to determine the effect of different structural variables like the existence of services, the organizational culture and the managers and colleagues support, on the stress experienced.

\section{Work-Life Reconciliation as an Issue of Resources and Barriers}

Reconciliation has been analyzed in terms of the factors that facilitate and restrict it, highlighting the tensions and contradictions between expectations, standards, practices, rights and ability to exercise them (Lopes, 2009). Decisions taken by women and men to balance work and family are weighted with a range of regulatory and structural constraints, as well as potential individual resources (Karkoulian et al., 2016).

Resources can be made available by the organization (organizational culture, work arrangements and schedules, access to rights, etc.), by public policies (maternity and paternity leaves, creation and/or enhancement of social facilities to support families, for example) or by the individual (access to paid domestic work; human capital; existence of family support networks). The obstacles have to do with the demands and professional needs, but also with the resistance of the organizations to the use of rights, with the hostile social contexts to reconciliation, with the reduced sense of rights of the individuals themselves, with conceptions of gender roles that reify double and triple shifts for women workers, among others.

Laura Dulk and Bram Peper (2007) have worked the issue of supports and barriers, as the two dimensions in the structural base of an organization with formal policies for work-family reconciliation. They sought to understand the fact that the workers do not use or mobilise the spectrum of resources provided by organizations (flexible hours, part-time work), and by public policies (right to paid parenting allowances, between others). It is therefore important to understand what factors affect that non-use. It is known, for example, that in Portugal in 2013, only $72.4 \%$ of men enjoyed the mandatory paternity leave, although this represents an increase in the number of parents who enjoyed their rights (Monteiro, 2014).

The study of the European project Quality of Life in a Changing Europe (Lippe et al., 2009), focused its analysis on the various assets owned by individuals in an area (work, for example) as elements that can contribute to improving the well-being and quality of life in another (such as family). The study also looked at the requirements/existing needs in the labour market and in the domestic sphere, and how they articulate with the capabilities of individuals (Rodrigues et al., 2010). The study compares eight European countries (Finland, Sweden, Holland, Germany, UK, Portugal, Hungary and Bulgaria), assuming that the working conditions, reconciliation policies and opportunities to achieve a workingfamily balance vary on national contexts, in accordance, for example, with the various welfare state regimes (Beham, Drobnič, \& Präg, 2014; Beham, Präg, \& Drobniĉ, 2012).

More specifically, Beham, Drobnič and Prag (2012) equated the difficulties of work-family reconciliation in relation to factors such as the type of public support for reconciliation and gender equality promoted in five of these countries (Sweden, UK, Netherlands, Germany and Portugal), in the services sector. These countries are differentiated by their welfare state schemes, with different levels of policies to reconciliation, support families and promote gender equality. They claim that the contextual elements are important as they influence the degree of support and resources available to 
individuals, and so determine the reconciliation opportunities for people. The focus is particularly made on the differences in organizational resources for reconciliation and its impact on the negative interference of the level of work on the family and the satisfaction with work-family balance of the reporting population.

They have adopted a conception of work requirements (work demands) that defines how workplace characteristics are associated with certain physiological and psychological costs; while the labour resources refer to the working environment aspects that increase the possibility of achieving goals, personal health and stimulate personal growth and development (Demerouti et al., 2001 as cited in Beham et al., 2014). As labour or organizational resources they point autonomy, flexibility, interrelational support and support to work-life balance. As work demands they point pressure and employment (in)security. On the side of family life, they identify as resources the marital status, the existence of paid domestic help, the absence of conflict, and the household income; and as demands, the domestic work and children care (Rodrigues et al., 2010).

In their study they determined three components involved in satisfaction with the work-family balance: the support of colleagues and supervisors to the relationship between the two spheres; professional requirements; the ability to share aspects of family life in the workplace (Beham et al., 2012).

They concluded that Portugal and Bulgaria are the countries where there are higher levels of work interference on the family and where the supports in the workplace are lower. Portugal is, therefore, one of the countries where the organizational context is less favourable to work-life reconciliation (Rodrigues et al., 2010). Yet it is also in these countries that people manifested most significantly a positive transfer of work on the family and vice versa, which will mitigate the perceptions of conflict, according to the research team. Although there have been differences by sex, and women reveal lower satisfaction levels with work-family balance, reconciliation problems are not exclusive to them, also affecting men, although there is a tendency to naturalize the women overload through gender roles.

The reception of reconciliation needs requires a change in the organizational culture, especially of the long working hours culture, which puts the full availability, and the overtime practice in the higher levels of assessing the dedication and commitment of employees. This culture determinates that people trying to preserve time to devote to their family and to personal matters are censored by managers and co-workers (Been et al., 2017; Hochschild, 1997; Li, Bagger, \& Cropanzano, 2017; Litano, Major, Landers, Streets, \& Bass, 2016; Thompson, Beauvais, \& Lyness, 1999). The perceptions of lack of organizational support to reconciliation reduce the use of rights, increase the sacrifice of family life, stress, produce less job satisfaction and more intent on changing jobs.

A family-friendly culture, or a reconciliation culture relates to how an organization values and allows the articulation of the various spheres of life of its workers. It usually includes: new work organization models (part-time, flexible schedules, job sharing, teleworking, time bank, ongoing journey, concentrating on four days of the week, etc.); care facilities for dependent family members (day care at the workplace, occupational activities for children, financial assistance, summer camps, agreements with social facilities, etc.); encouraging the use of maternity and paternity rights (parenting leave, layoffs to care for family members, etc.); health services, sports and welfare for workers and their families; support mechanisms (training/awareness of managers, information services for workers; staff needs assessments, plans for equality, etc.). As can be seen, some allow to spend more time with family, and the other, freeing the person of family and personal concerns, let devote more time to work. In her study, Arlie Hochschild (1997) found out that the most implemented are the latter. Organisation for Economic Cooperation and Development (OECD, 2001) states that employees alone can decide whether or not a work organization is family supportive.

Among the organizational factors that may constitute barriers or facilitate reconciliation with influence on stress and satisfaction, it has been highlighted the role of managers and supervisors (Been et al., 2017; Dulk \& Peper, 2009; Ferreira, 2004; Li et al., 2017; Litano et al., 2016; Lopes, 2009). Lopes (2009) found out an awareness of hostility and blockade on the part of managers and co-workers to the 
enjoyment of the rights associated with parenthood, in Portugal. The power of managers is discretionary and variable, and the fact that it is a group that diligently seeks to demonstrate the ideal of absolutely engaged and committed worker, doing long hours of work, generally is the one that most sacrifices his own family and does not use the reconciliation measures (Dulk \& Peper, 2009). In their study of the sense of rights by employees of a local authority, Monteiro and Domingos (2013) identified two major barriers that hinder particularly the use of maternity and paternity leaves and absence from work to provide family assistance: the fragility of contractual relationship and the lack of sensitivity from managers. They also concluded that the type of entity, in this case a public sector entity, may be a factor that justifies greater tolerance and receptivity to the enjoyment of licenses as stated in the literature (Dulk \& Peper, 2007; Lewis, 1998). The workers interviewed identified reasons for the public sector to be more facilitator, in particular, a greater obligation in law enforcement; being a sector not directed for profit; there is no mass production; there is a larger number of staff, and more possibilities of substitution; the highest level of knowledge of rights by the staff; less pressure on the workers; the fewer hours worked in the civil service (Monteiro \& Domingos, 2013).

With flexible forms of working time, organization may facilitate reconciliation, reducing the tension felt, the truth is that they are not always welcomed by the organizations, causing fear of costs increase, loss of control, among others. For example, in Portugal the Labour Code provides the possibility of the worker with children under 12 years of age or disabled or chronically ill, that lives with him/her in communion of table and housing, has the right to work part-time or in a flexitime system. The employer that intends to refuse should ask legal opinion from the Committee on Equality in Work and Employment, a national ombudsman. It is interesting that the main clients of this ombudsman have been public bodies, whose heads of human resources departments systematically rejects the right to flexible hours for convenience of services, or because the authorization will create a precedent that will open a big problem if after all workers want the same (Monteiro \& Ferreira, 2013). In studies of municipalities, we found out that the most desired work schedule is the flexible one (Monteiro \& Domingos, 2013). However, in sectors where labour rights are less protected, the fear of career costs for workers or even of reprisals justifies some resistance or reduced adherence to flexible working arrangements in Portugal. Gender and ideal worker conceptions, the evaluation criteria still based on availability, feedback from supervisors and colleagues, the income reduction and fear of negative effects on progression reduce employees' flexible work arrangements (Giannikis \& Mihail, 2011), especially by men (Adame, Caplliure, \& Miquel, 2016).

Following this assumptions, we have formulated the following hypotheses: the existence of reconciliation services promotes a perception of reconciliation capability (H1a); the existence of a supportive organizational culture promotes a perception of reconciliation capability $(\mathrm{H} 1 \mathrm{~b})$; the non existence of services and a non supportive culture is related with stress feelings by employees $(\mathrm{H} 2)$; the perception of support from managers and colleagues is related to reconciliation capability (H3); the perception of support from managers and colleagues is related to stress feelings by employees (H4).

\section{Method}

In order to analyze employees perspectives we have constructed a survey with a questionnaire composed by 5 parts ( 1 - reconciliation services and organizational supportive culture; 2 - managers and colleagues support; 3 - reconciliation capability; 4 - stress perceptions; 5 - sociodemographic data).

The study has been submitted to the assessment and approval by the management of 4 enterprises. The questionnaires were preceded by a page informing the subjects about the study aims, the importance of employees participation and confidentiality. That page also contained several socio-demographic questions. In line with the ethical requirements, it was emphasized that participants' cooperation was voluntary and that their answers were confidential and would only be used for the purpose of this study. Then, the self-report questionnaires were filled in by the volunteers in the presence of the researcher taking, on average, forty minutes. All participants provided their written informed consent. 
Data collection took place between March and May 2014, in the industrial park of Viseu, a district in the central part of Portugal. The enterprises and services were chosen to the sample because they were part of a regional equality and diversity plan, involving four enterprises (SMEs) and one public service. One of the goals of this plan is to produce changes in human resources strategies and policies, particularly to act on reconciliation difficulties previously detected by the project team. The employees included in the sample must have a dependent and paid employment (entrepreneurs excluded), and were employed full time in the enterprises and public service that constituted the sample.

The sample consisted of 136 employees. $57.4 \%$ of the employees were female; $71 \%$ had childcare responsibilities, and only $8.8 \%$ had elderly care responsibilities. In terms of education, $36.8 \%$ had a secondary degree and $25.7 \%$ had a high school degree. $72 \%$ work in medium size firms. Finally, $30 \%$ work in the public sector.

To translate the different components of the scale, we have applied the translate - translate back method (Hill \& Hill, 2012). The original version of the items included in the survey was translated independently to Portuguese by a specialist in the area of study with a high-quality use of English and Portuguese. Retroversion of the items was conducted by a bilingual translator, and translated and backtranslated versions of the scale were compared. Given the similarities presented by versions, we have proceeded to a pilot study by the administration of the survey to a sample of five employees, to test the comprehensiveness of the Portuguese version. As a consequence of this procedure, no changes proved necessary to the final version of the instrument.

To inquire about reconciliation services and organizational supportive culture, we have used items from Feierabend, Mahler and Staffelbach (2011), that present the following 2 dimensions: The existence and quality of services - My company offers more family-supportive services compared to other companies (quantity); The family-supportive services are according to the needs of the employees (quality). The Cronbach's Alpha obtained for this dimension is $\alpha=.88$. And the culture itself: The management is supportive for the reconciling of work and family (management culture); Many managers are hired with family care responsibilities (careers). The Cronbach's Alpha obtained for this scale is $\alpha=.60$. The respondents rated the supportive organizational culture on a scale of 1 to 5 (1= strongly disagree, $5=$ strongly agree).

To measure managers and colleagues support, we used Beham et al. (2012) items: My direct superior supports workers who want to switch to less demanding work for personal reasons; My direct superior supports workers who want to (temporarily) reduce their working hours for personal reasons; I am comfortable in discussing my private life with my direct superior; My colleagues support workers who want to (temporarily) reduce their working hours for personal reasons; My colleagues support employees who want to move to less demanding work for personal reasons; I am comfortable in discussing aspects of my private life with my colleagues. The respondents rated the supportive organizational culture on a scale of 1 to $5(1=$ strongly disagree, $5=$ strongly agree $)$. The Cronbach's Alpha obtained for this scale is $\alpha=.78$.

To analyze reconciliation capability we have used the following items: How easy or difficult it is to reconcile the demands of your work and personal and family life (scale $1=$ very easy, 5 very difficult); I have enough time outside working hours, to maintain the balance between family and working life (scale 1= strongly agree, 5 strongly disagree); When I'm on vacation I can forget about work and enjoy the holidays (scale $1=$ strongly agree, 5 strongly disagree); Overall, do you feel successful when trying to reconcile family with working life (on a scale of 1 to $5 ; 1=$ very well, 5 nothing well); How many times, when you get home, you feel exhausted due to work pressures and problems (on a scale of 1 never, 5 always). The Cronbach's Alpha obtained for this scale is $\alpha=.79$.

Finally, stress perceptions has been studied by the item In the last month, how often have you felt stressed due to work (on a scale of 1 never, 4 always) and the item In the last month, how often have you felt stressed due familiar. 
Structural equation modeling was used to analyze the relationships between variables (Jöreskog \& Sörbom, 1989; Kelloway, 1998). Modelling data through structural equations has similar principles as the ones of multiple regression. However, it reveals to be a stronger process since it allows interactions, nonlinearities, correlated errors, errors of measurement, latent (independent) multiple variables each one measured with different items. It is an extension of the generalized linear models, of which multiple regression is an example. In this study we use confirmatory factorial analysis (CFA) as a special case of structural equations application. The CFA is a model that examines the relations between observed and latent variables and respective correlations. This model is based on observational and or theoretical information which allows the analyst to specify the structure of the model before the analysis, as opposed to exploratory factorial analysis where one aims to find the model. Thus, in this case, the results show evidence (or not) that the data supports the model proposed.

This type of analysis is very common in behavior studies, psychology, psychiatry and in marketing, where many variables of interest are measured indirectly.

The elaboration of a latent variable is made in the measurement model, in which the indicators of the latent variable are specified. The models proposed were estimated using Software SPSS Inc v.20 and Software AMOS v.19. Instead of excluding cases without information, full information maximum likelihood (FIML) estimation was used. The standardized coefficients (SC) were interpreted according to Kline (2011), where an SC of about .10 indicates a small effect, an SC of about .30 indicates a medium effect, and $\mathrm{SC}>.50$ indicates a strong effect.

\section{Results}

A structural equation model was conducted to test whether the factor solution of the perception of the reconciliation capability - STRESS model demonstrated a goodness of fit to the population studied. Under the usual principles the model was assessed using the following goodness-of-fit statistics: normed chi-square statistic $(\chi 2)$, comparative fit index (CFI), Tucker and Lewis index (TLI) and root mean square error of approximation (RMSEA). A good fit is obtained when the Normed $\chi 2$ is 2 or lower, the CFI, GFI and TLI are .90 or higher, and the RMSEA is .10 or lower. The assumption of normality of the items and the existence of outliers was assessed.

Figure 1 shows the structural model perception of the reconciliation capability - STRESS. This model illustrates the relation between the explanatory variables, the mediator and the dependent variable. This model is similar to the regression models and allows for the evaluation of the relative importance of variables in the model. The results presented from the figure showed that the perception of the reconciliation capability is a total mediator of the relation of the support with the stress, the direct effect of each support was tested but proved to be non-significant. Also the labor stress is a total mediator of the relation between reconciliation perception and family stress. 


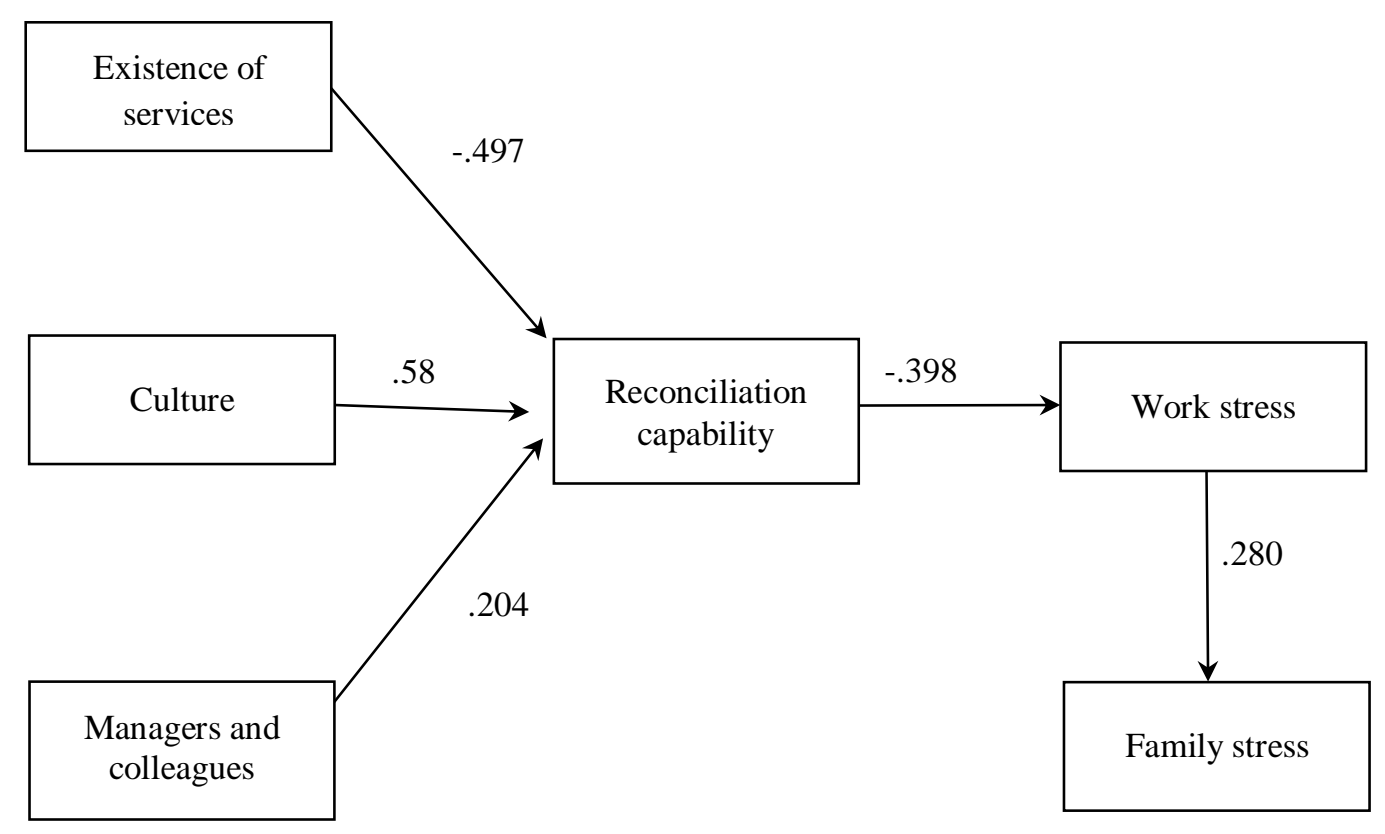

Figure 1. Structural Equation Model

The models including the stress as the response variable presented satisfactory fit indices a significant $\chi 2 / \mathrm{df}=1.422 ;(\mathrm{p}<0.001)$. The model presented an RMSEA of $0.056 ; \mathrm{p}<.001$ indicating a good fit and TLI of 0.958 and a CFI of 0.980 . In view of the regression weights we distinguish between an existence of services given by items 15.1 and 15.2 which conducts to a lower perception of the reconciliation capability (-0.497) and a personal support given by the organizational behavior (15.5 and 15.6) and by management support (17.4-17.9) which conducts to increase the perception reconciliation capability 0.581 and 0.204 respectively. The perception of the reconciliation capability has a negative impact on the labor stress -0.398 and the labor stress has a positive impact on familiar stress 0.280 .

Our initial hypotheses $\mathrm{H} 1 \mathrm{~b}, \mathrm{H} 2, \mathrm{H} 3$ and $\mathrm{H} 4$ were completely confirmed given the tested influence of the perception of support from managers and colleagues on reconciliation capability; and of the reconciliation capability (as a moderator variable) with stress feelings by employees. Our first hypothesis (H1a) which stated that the existence of reconciliation services promotes a perception of reconciliation capability was not verified, given the reduced influence of the existence of services.

\section{Conclusion}

We have stated earlier that decisions taken by women and men to balance work and family are weighted with a range of regulatory and structural constraints, as well as potential individual resources. With this study, we can show the important relation that exists between organizational cultures and support on work-family reconciliation capabilities of their employees, and the influence of these in work and family stress. We have demonstrated that more important than the existence of reconciliation services, the perceptions of support by the organization and by managers and colleagues give individuals a sense of reconciliation capability. This confirms that the simple existence of reconciliation measures does not mean that employees feel entitled to them (Beham et al., 2012). This may explain why people do not use or feel inhibited to the use of reconciliation policies displayed by organizations or by the state, preferring to sacrifice their family lives (Monteiro, 2014). These conclusions are fundamental in a country such as Portugal, where there is limited research on causal relations justifying work-life reconciliation difficulties. 
It is a conclusion that endorses some literature which states that Portugal is one of the countries where the perceptions of support in the workplace are lower, and where the organizational context is less favourable to work-life reconciliation (Rodrigues et al., 2010). The persistence of organizational cultures that censures employees who try to preserve time to devote to their family or their personal issues may explain these perceptions. In fact, there is evidence on the presence of a presenteeism culture that prevails in employee's assessment (Mimoso, 2013; Yaphe, 2015).

This endorses literature conclusions that emphasize that the reception of reconciliation requires a change in the organizational culture, especially in the long working hours culture, and in the managers attitude and leadership style (Been et al., 2017; Li et al., 2017; Litano et al., 2016) which puts the full availability and the doing of overtime as top criteria for the assessment of employees performance. A new culture must be made available, where managers support employee's reconciliation needs and ambitions. The perceptions of organizational support to reconciliation amplify the sense of rights, reducing the sacrifice of family life, stress, and may produce job satisfaction. We also confirm that it is work stress that impacts on the family and not the contrary.

As an action research, this study has some limitations. Despite the abundance of SMEs in the region studied, the presence of work-life reconciliation policies in such firms is scarce. In the future, scholars should repeat the study with a larger sample, including larger firms to compare results between these two types of firms. The questionnaire showed good replication potential to other samples, at a national scale and with a more diverse range of organizations. In future research, it will be interesting to compare organizations that have structured policies on reconciliation with organizations that do not have them.

\section{References}

Adame, C., Caplliure, E.-M., \& Miquel, M.-J. (2016). Work-life balance and firms: A matter of women? Journal of Business Research, 69(4), 1379-1383. https://doi.org/10.1016/j.jbusres.2015.10.111

Been, W. M., Lippe, T. van der, Dulk, L. den, Guerreiro, M. das D. H., Mrcela, A. K., \& Niemisto, C. (2017). European top managers' support for work-life arrangements. Social Science Research, 65, 60-74. https://doi.org/10.1016/j.ssresearch.2017.02.004

Beham, B., Drobnič, S., \& Präg, P. (2014). The work-family interface of service sector workers: A comparison of work resources and professional status across five european countries. Applied Psychology, 63(1), 29-61. https://doi.org/10.1111/apps.12012

Beham, B., Präg, P., \& Drobniĉ, S. (2012). Who' s got the balance? A study of satisfaction with the work-family balance among part-time service sector employees in five western European countries. The International Journal of Human Resource Management, 23(18), 3725-3741. http://dx.doi.org/10.1080/09585192.2012.654808

Brun, E., \& Milczarek, M. (2007). Expert forecast on emerging psychosocial risks related to occupational safetyand health. Luxembourg: Office for Official Publications of the European Communities. Retrieved from https://osha.europa.eu/en/tools-andpublications/publications/reports/7807118

Byrne, G. J., \& Pachana, N. A. (2011). Development and validation of a short form of the geriatric anxiety inventory - the GAI-SF. International Psychogeriatrics, 23(1), 125-131. https://doi.org/10.1017/S1041610210001237

Carlson, D., \& Kacmar, K. M. (2000). Work-family conflict in the organization: Do life role values make a difference? Journal of Management, 26(5), 1031-1054. https://doi.org/10.1016/S01492063(00)00067-2 
Cunha, M. J., Pereira, J. P., \& Cunha, J. M. (2014). Gerir pessoas e competências - Uma estratégia de sucesso - Apresentação do relatório de avaliação de perfil de riscos psicossociais. Lisboa: Associação Portuguesa de Psicologia da Saúde Ocupacional.

Dulk, L. den, \& Peper, B. (2007). Working parents' use of work-life policies. Sociologia, Problemas e $\begin{array}{llll}\text { Práticas, } & \text { (53), 51-70. } & \text { Retrieved } & \text { from }\end{array}$ http://www.scielo.mec.pt/scielo.php?script=sci_arttext\&pid=S0873$65292007000100003 \& \operatorname{lng}=\mathrm{pt} \& \operatorname{lng}=\mathrm{en}$

Dulk, L. den, \& Peper, B. (2009). Managing work-life policies in the European workplace: Explorations for future research. Edinburgh: Erasmus University.

Esson, P. L. (2004). Consequences of work-family conflict: Testing a new model of work-related, nonwork related and stress-related outcomes (Master thesis). Virginia Polytechnic Institute and State University, Blacksburg, Virginia, USA.

European Foundation for the Improvement of Living and Working Conditions. (2007). A review of working conditions in France. Retrieved from https://www.eurofound.europa.eu/sites/default/files/ef_files/ewco/surveys/FR0603SR01/FR060 3SR01.pdf

European Foundation for the Improvement of Living and Working Conditions. (2009). Second European quality of life survey: Overview, publications office of the European Union, Luxembourg. Retrieved from https://www.eurofound.europa.eu/sites/default/files/ef_files/pubdocs/2009/02/en/2/EF0902EN.pdf

Feierabend, A., Mahler, P., \& Staffelbach, B. (2011). Are there spillover effects of a family supportive work environment on employees without childcare responsibilities? Management Revue, 22(2), 188-209. Retrieved from http://www.jstor.org/stable/41783681

Ferreira, V. do C. (2004). Relações sociais de sexo e segregação do emprego: Uma análise da feminização dos escritórios em Portugal (Doctoral dissertation). Faculdade de Economia da Universidade de Coimbra, Coimbra, Portugal.

Friedman, S. D., \& Greenhaus, J. H. (2000). Work and family - allies or enemies? What happens when business professionals confront life choices. New York: Oxford University Press.

Giannikis, S. K., \& Mihail, D. M. (2011). Modelling job satisfaction in low-level jobs: Differences between full-time and part-time employees in the Greek retail sector. European Management Journal, 29(2), 129-143. https://doi.org/10.1016/j.emj.2010.12.002

Hill, M. M., \& Hill, A. (2012). Investigação por questionário (2a ed.). Lisboa: Edições Sílabo.

Hochschild, A. R. (1997). The time bind: When work becomes home \& home becomes work. New York: Academy of Management.

Jöreskog, K. G., \& Sörbom, D. (1989). LISREL 7: A guide to the program and applications. Chicago: SPSS Publications.

Karkoulian, S., Srour, J., \& Sinan, T. (2016). A gender perspective on work-life balance, perceived stress, and locus of control. Journal of Business Research, 69(11), 4918-4923. https://doi.org/10.1016/j.jbusres.2016.04.053

Kelloway, E. K. (1998). Using LISREL for structural equation modeling: A researcher's guide. Thousand Oaks: Sage Publications.

Kline, R. B. (2011). Principles and practice of structural equation modeling analysis (3rd ed.). New York: The Guilford Press. 
Lewis, S. (1998). O sentido dos direitos a apoios para a conciliação entre trabalho e vida familiar: $O$ caso do Reino Unido. Retrieved from https://repositorio.iscte-iul.pt/bitstream/10071/770/1/4.pdf

Lewis, S., Anderson, D., Lyonette, C., Payne, N., \& Wood, S. (Eds.). (2016). Work-life balance in times of recession, austerity and beyond: Meeting the needs of employees, organizations and social justice. New York: Routledge.

Li, A., Bagger, J., \& Cropanzano, R. (2017). The impact of stereotypes and supervisor perceptions of employee work-family conflict on job performance ratings. Human Relations, 70(1), 119-145. https://doi.org/10.1177/0018726716645660

Lippe, T. van der, Dulk, L. den, Doorne-Huiskes, A. Van, Lane, L., \& Bäck-Wiklund, M. (2009). Final report quality in a changing Europe. Deliverable of EU-project Quality, Utrecht, Utrecht University, Netherlands.

Litano, M. L., Major, D. A., Landers, R. N., Streets, V. N., \& Bass, B. I. (2016). A meta -analytic investigation of the relationship between leader-member exchange and work-family experiences. The Leadership Quarterly, 27(5), 802-817. https://doi.org/10.1016/j.leaqua.2016.06.003

Lopes, M. (2009). Trabalho e parentalidade: Um estudo sobre a acomodação e custos da maternidade e da paternidade para os indivíduos e as organizações (Master thesis). Faculdade de Economia, Universidade de Coimbra, Portugal.

Mimoso, S. C. A. (2013). A cultura da presença em Portugal: Contributos para a definição do conceito. Lisboa: ISCTE-IUL.

Monteiro, R. (2014). A conciliação trabalho-família e os riscos psicossociais. In H. Neto, J. Areosa \& P. Arezes (Eds.), Manual sobre riscos psicossociais no trabalho (pp. 131-151). Porto: Civeri RICOT.

Monteiro, R., \& Domingos, L. (2013). O sentido do direito à conciliação: Vida profissional, familiar e pessoal numa autarquia. Sociologia, Problemas e Práticas, 1(73), 59-77. Retrieved from http://spp.revues.org/1310

Monteiro, R., \& Ferreira, V. (2013). Planos para a igualdade de género nas organizações: Contributo para o desenho e realização dos diagnósticos organizacionais. Sociedade e Trabalho, (44), 123136.

Nohe, C., Meier, L. L., Sonntag, K., \& Michel, A. (2015). The chicken or the egg? A meta-analysis of panel studies of the relationship between work-family conflict and strain. Journal of Applied Psychology, 100(2), 522-536. http://dx.doi.org/10.1037/a0038012

Organisation for Economic Cooperation and Development. (2001). OECD employment outlook 2001. Paris: OECD Publishing. http://dx.doi.org/10.1787/empl_outlook-2001-en

Rodrigues, E., Barroso, M., \& Caetano, A. (2010). Trabalho , família e bem-estar: Factores e padrões de qualidade de vida na Europa [CIES e-working paper N. ${ }^{\circ}$ 93/2010]. Centro de Investigação e Estudos de Sociologia, Lisboa, Portugal. Retrieved from http://www.cies.iscte.pt/destaques/documents/CIES-

WP93Rodrigues_Barroso_Caetano_001.pdf

Thompson, C. A., Beauvais, L. L., \& Lyness, K. S. (1999). When work-family benefits are not enough: The influence of work-family culture on benefit utilization, organizational attachment, and workfamily conflict. Journal of Vocational Behavior, 54(3), 392-415. http://dx.doi.org/10.1006/jvbe.1998.1681 
Xie, J., Shi, Y., \& Ma, H. (2017). Relationship between similarity in work-family centrality and marital satisfaction among dual-earner couples. Personality and Individual Differences, 113, 103-108. https://doi.org/10.1016/j.paid.2017.03.021

Yaphe, J. (2015). Presenteeism: Why we work when we are sick. Revista Portuguesa de Medicina Geral $e$ Familiar, 31(4), 242-243. Retrieved from http://www.scielo.mec.pt/scielo.php?script=sci_arttext\&pid=S2182$51732015000400002 \&$ nrm $=$ iso

\title{
Authors' Profiles
}

\author{
Rosa Monteiro \\ Largo Cruz de Celas 1, 3000-132, Coimbra, Portugal. E-mail address: monteiro.rosa14@ gmail.com \\ Marta Pereira \\ Largo Cruz de Celas 1, 3000-132, Coimbra, Portugal. E-mail address: mmartapereira@gmail.com \\ Fernanda Daniel \\ Largo Cruz de Celas 1, 3000-132, Coimbra, Portugal. E-mail address: fernanda-daniel@ismt.pt \\ Alexandre Gomes da Silva \\ Quinta Agrícola, Bencanta, 3040-316, Coimbra, Portugal. E-mail address: asilva@iscac.pt \\ Fátima Regina Ney Matos \\ Largo Cruz de Celas 1, 3000-132, Coimbra, Portugal. E-mail address: fneymatos@ismt.pt
}

